\title{
Development of Heterogeneous Basic Catalysts Supported on Silica for the Synthesis of High Quality Bio-Diesel from Waste Cooking Oil
}

\author{
Paweesuda NATewong, Yayoi MuraKami, Haruki TAni and Kenji ASAmi \\ (Received August 5, 2015)
}

\begin{abstract}
Effect of addition of $\mathrm{CaO}$ and $\mathrm{ZrO}_{2}$ to $\mathrm{MgO} / \mathrm{SiO}_{2}$ catalyst, which is effective for synthesis of High Quality BioDiesel (HiBD) was investigated using atmospheric agitated reactor at $430^{\circ} \mathrm{C}$ and LHSV $=0.3 \mathrm{~h}^{-1}$. Binary MgO$\mathrm{CaO} / \mathrm{SiO}_{2}$ and $\mathrm{MgO}-\mathrm{ZrO}_{2} / \mathrm{SiO}_{2}$ catalysts and ternary $\mathrm{MgO}-\mathrm{CaO}-\mathrm{ZrO}_{2} / \mathrm{SiO}_{2}$ catalyst were prepared by the incipient wetness impregnation method. Physical properties of these catalysts were characterized by XRD and BET methods. Both the fatty acids and the triglycerides in waste cooking oil were converted into hydrocarbon gases, $\mathrm{CO}, \mathrm{CO}_{2}$, water and hydrocarbon oil. $\mathrm{CaO}$ - and/or $\mathrm{ZrO}_{2}$-added catalysts gave higher $\mathrm{CO}_{2}$ yields than $\mathrm{MgO} / \mathrm{SiO}_{2}$ alone, and showed lower acid values. These observation indicates that the added oxides promote the decarboxylation reactions. Iodine values also decreased to some extent by the addition of these oxides.

高品質のバイオデイーゼル ( $\mathrm{HiBD)}$ の合成に効果的な $\mathrm{MgO} / \mathrm{SiO}_{2}$ 触媒に対する $\mathrm{CaO}$ および $\mathrm{ZrO}_{2}$ の添加効果を, 常圧擋拌 式反応器を用い, $430{ }^{\circ} \mathrm{C}, \mathrm{LHSV}=0.3 \mathrm{~h}^{-1}$ の条件下で検討した。 $\mathrm{MgO}-\mathrm{CaO} / \mathrm{SiO}_{2}, \mathrm{MgO}-\mathrm{ZrO}_{2} / \mathrm{SiO}_{2}$ の二元触媒および $\mathrm{MgO}$ $\mathrm{CaO}-\mathrm{ZrO}_{2} / \mathrm{SiO}_{2}$ 三元触媒は incipient wetness 含浸法で調製し，XRD および BETにより物性を評価した。廃食油中に含まれる 脂肪酸と油脂 (トリグリセリド) の両者が, 炭化水素ガス, $\mathrm{CO}, \mathrm{CO}_{2}$, 水および炭化水素油に転化した。 $\mathrm{CaO}$ 拈び $\mathrm{ZrO}_{2}$ を添加し た触媒は, 無添加の $\mathrm{MgO} / \mathrm{SiO}_{2}$ 触媒よりも高い $\mathrm{CO}_{2}$ 収率を与え, 生成油の酸価值は低くなった。このことは, 添加された酸化物 が脱炭酸反応を促進することを示す。たたれらの酸化物の添加により，ヨウ素価もある程度低減されることが分かった。
\end{abstract}

\section{Key Words}

High quality bio-diesel, $\mathrm{MgO} / \mathrm{SiO}_{2}$ catalyst, $\mathrm{CaO}$ and $\mathrm{ZrO}_{2}$ addition

\section{Introduction}

The production of bio-fuels as clean and renewable fuels has recently been paid a keen attention to because of a rapid price rise of petroleum and an increase in the greenhouse gas emission. Fatty acid methyl ester (FAME) and Bio Hydrofined Diesel (BHD) are known as current bio fuels from triglycerides of vegetable oils and animal fats for diesel engine ${ }^{12}{ }^{2}$. However, sub-raw materials other than oil are required in both FAME and BHD production processes; methanol and high pressure hydrogen gas are necessary for FAME and BHD, respectively.

We have developed a new biodiesel production process which gives mixed hydrocarbon liquids of diesel fraction with high selectivity without using any sub-

Faculty of Environmental Engineering, The University of Kitakyushu

1-1, Hibikino, Wakamatsu-ku, Kitakyushu-shi, Fukuoka 808-0135, Japan materials ${ }^{3)}{ }^{6}$, and named this fuel as High Quality BioDiesel (HiBD) ${ }^{7}$. HiBD is expected as the next generation biodiesel because its properties are suitable for the latest common rail type engine. The production process of HiBD is quite simple, where triglycerides are converted to liquid hydrocarbons and light hydrocarbon gases though decarboxylation over solid catalysts as shown in Fig. 1. This process can be adapted to a lot of feed materials such as vegetable oil, waste cooking oil, and animal fats.

One of the most significant factors in the HiBD production is the catalyst which promotes the conversion of triglycerides. A magnesium oxide supported on silica (MgO/ $\mathrm{SiO}_{2}$ ) catalyst is found to be effective for this reaction, and its basic property promotes the decarboxylation ${ }^{3) \sim 6)}$. Since both $\mathrm{CaO}$ and $\mathrm{ZrO}_{2}$ are known to have basic character and also ability to enlarge active surface area ${ }^{8}$, and thus they are expected to enhance the activity. In the present study, therefore, addition of $\mathrm{CaO}$ and $\mathrm{ZrO}_{2}$ to $\mathrm{MgO} / \mathrm{SiO}_{2}$ catalyst 


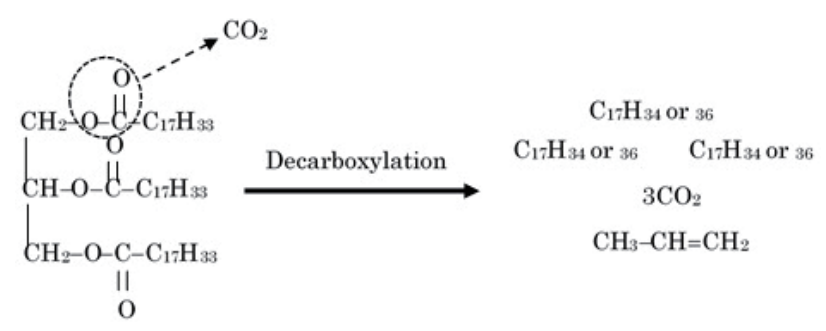

Fig. 1 The target reaction scheme

was investigated.

\subsection{Preparation of catalyst}

\section{Experimental}

Silica-supported oxide catalysts were prepared by the incipient wetness impregnation method using aqueous solutions of $\mathrm{Mg}, \mathrm{Ca}$, and $\mathrm{Zr}$ nitrates. The silica support used was Fuji Silisia Q10 (particle size, 1.18-2.36 mm; SA $300 \mathrm{~m}^{2} / \mathrm{g}$; PV, $0.95 \mathrm{~cm}^{3} / \mathrm{g}$ ). After the impregnation, they were dried in an oven at $100{ }^{\circ} \mathrm{C}$ for $12 \mathrm{~h}$, and then calcined in air at $500{ }^{\circ} \mathrm{C}$ for $3 \mathrm{~h}$. Components of the catalysts are abbreviated by using loadings (wt\%) and the initial letters of the oxides; for example, 5M5C5Z indicates that the catalyst contains $5 \mathrm{wt} \%$ of $\mathrm{MgO}, 5 \mathrm{wt} \%$ of $\mathrm{CaO}$, and $5 \mathrm{wt} \%$ of $\mathrm{ZrO}_{2}$, respectively. Physical properties of these catalysts were characterized by X-ray diffraction and $\mathrm{N}_{2}$ adsorption.

\subsection{Catalytic test}

Catalytic reactions were conducted in an agitated reactor system at $430^{\circ} \mathrm{C}$ under atmospheric pressure. Fig. 2 shows the experimental setup for the HiBD production. 25 $\mathrm{g}$ of the granular catalyst was charged into the reactor, and it was heated up to the reaction temperature in an He flow $(50 \mathrm{~mL} / \mathrm{min})$. Waste cooking oil with an acid value of $39.123 \mathrm{mg}-\mathrm{KOH} / \mathrm{g}$-oil and iodine value of $101 \mathrm{~g}-\mathrm{I} / 100 \mathrm{~g}$-oil, which was supplied from the university restaurant, was introduced into the catalyst bed at $0.25 \mathrm{~mL} / \mathrm{min}$ with a

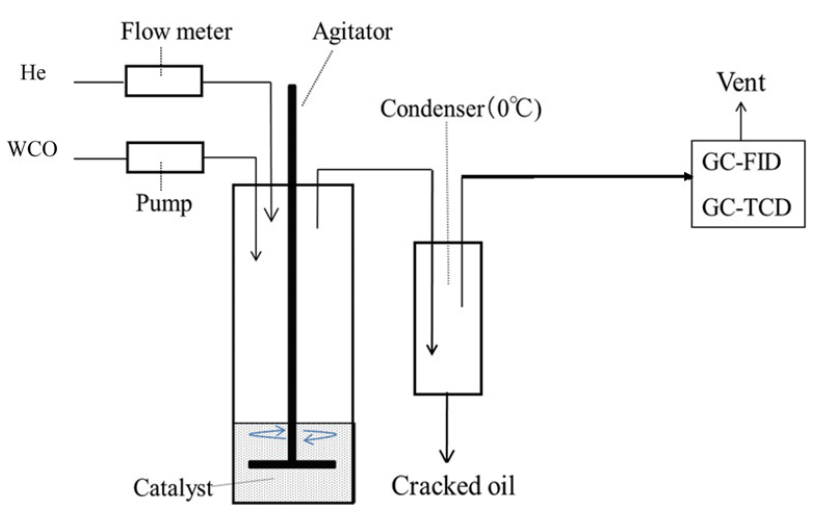

Fig. 2 Reaction apparatus for cracking oils pump. The gaseous products which came out from the reactor were cooled and condensed at $0^{\circ} \mathrm{C}$, the uncondensed gaseous products were sampled and analyzed every 30 minutes during the reaction by a gas chromatograph with thermal conductivity detector (GC-TCD) and one with flame ionization detector (GC-FID) on line. Yields of the cracked oil and water were calculated on the basis of weight of the reactant oil fed. Carbon number distribution of the product oil was analyzed off line with another GC-FID. The amount of residue was determined by weight difference between catalysts before and after use. Total acid value, index of free acid contents, and iodine value, index of the amount of unsaturated bonding, of the oil were measured by potentiometric titration methods according to JIS 2501-2003 and JIS K0070-1992, respectively.

\section{Results and Discussion}

Table 1 shows the specific surface area (SA) and the pore volume (PV) of the fresh catalysts. When $\mathrm{CaO}$ and/ or $\mathrm{ZrO}_{2}$ was added to the $\mathrm{MgO} / \mathrm{SiO}_{2}$ catalyst, both $\mathrm{SA}$ and $\mathrm{PV}$ of the catalysts increased. This suggests that $\mathrm{CaO}$ and $\mathrm{ZrO}_{2}$ have similar effect on surface area and pore volume. The highest SA and PV were obtained with $5 \mathrm{M} 5 \mathrm{C} 5 \mathrm{Z} / \mathrm{SiO}_{2}$ catalyst.

Fig. 3 shows the XRD patterns of the fresh catalysts. In each case, only a broad diffraction line due to $\mathrm{SiO}_{2}$ support was observable, and no peaks derived from the

Table 1 BET surface area and pore volume

\begin{tabular}{c|c|c}
\hline Catalysts & $\begin{array}{c}\mathrm{SA} \\
\left(\mathrm{m}^{2} / \mathrm{g}\right)\end{array}$ & $\begin{array}{c}\mathrm{PV} \\
\left(\mathrm{cm}^{3} / \mathrm{g}\right)\end{array}$ \\
\hline $10 \mathrm{M} / \mathrm{SiO}_{2}$ & 186 & 43 \\
$5 \mathrm{M} 5 \mathrm{C} / \mathrm{SiO}_{2}$ & 213 & 49 \\
$5 \mathrm{M} 5 \mathrm{~S} / \mathrm{SiO}_{2}$ & 253 & 58 \\
$5 \mathrm{M} 5 \mathrm{C} 5 \mathrm{Z} / \mathrm{SiO}_{2}$ & 335 & 77 \\
\hline
\end{tabular}

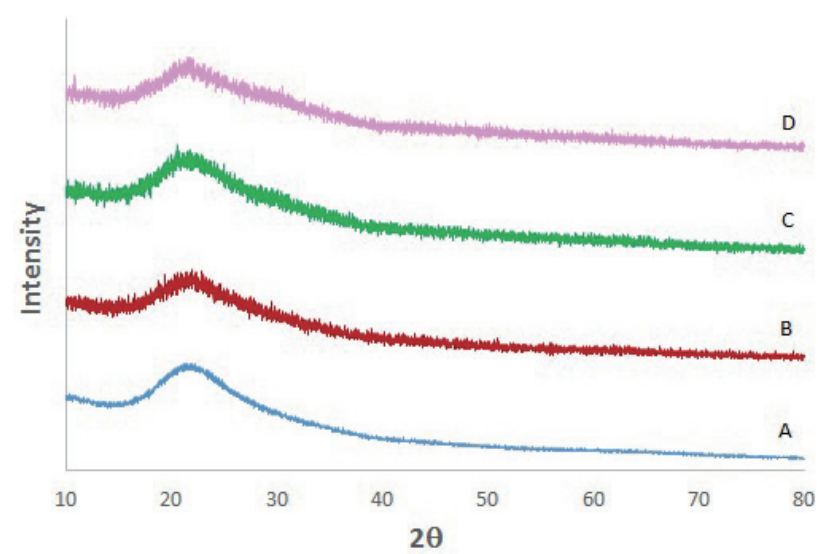

Fig. 3 XRD patterns of A) $10 \mathrm{M} / \mathrm{SiO}_{2}$, B) $5 \mathrm{M} 5 \mathrm{C} / \mathrm{SiO}_{2}$, C) $5 \mathrm{M} 5 \mathrm{Z} /$ $\mathrm{SiO}_{2}$ and D) $5 \mathrm{M} 5 \mathrm{C} 5 \mathrm{Z} / \mathrm{SiO}_{2}$ catalysts 
supported oxides of $\mathrm{MgO}, \mathrm{CaO}$, and $\mathrm{ZrO}_{2}$ were detectable. Thus, these species would exist as highly dispersed ones on the support ${ }^{91}$ 10).

Fig. 4 shows product yield from waste cooking oil over the oxide catalysts by decarboxy-cracking. The major products recovered were cracked oil, dry gas $\left(\mathrm{C}_{1}-\mathrm{C}_{4}\right.$ hydrocarbons), $\mathrm{CO}, \mathrm{CO}_{2}$, water and residue. The unreacted fatty acids was not detected, as the reacted fatty acids and the unreacted fatty acids may be condensed into liquid products. Therefore, liquid products not only contain the cracked oils but also comprise the unreacted fatty acids. Unreacted fatty acids would also remain as residue. $\mathrm{CO}_{2}$ yields with $\mathrm{CaO}$ and $\mathrm{ZrO}_{2}$ added catalysts were $1.1 \sim 1.4$ times higher than that with $\mathrm{MgO} / \mathrm{SiO}_{2}$ catalyst. These facts show that the added oxides would assist $\mathrm{MgO}$ and promote the decarboxylation from intermediate free acids as well as triglycerides ${ }^{11}{ }^{12}$. The increase in the specific surface area would be another effect as shown in Table 1. Formation of $\mathrm{CO}$, even the yield was low, was observed over each catalyst. It may be formed by the decomposition of ketones as by-products ${ }^{11}{ }^{12)}$ or through the reverse watergas shift reaction.

Fig. 5 shows the carbon number distribution of the product oil. GC-MS analysis was done by area normalization method, which revealed that more than 99 wt\% of the oil were hydrocarbons, and very small amount of free fatty acids and alcohols with different carbon numbers were contained. As a whole, the distribution profiles are similar to each other; a large amount of hydrocarbons with the diesel fraction $\left(\mathrm{C}_{10}-\mathrm{C}_{20}\right)$ are the major products, while the compounds with carbon number higher than 21 were not observed. The main product obtained with the catalysts except for $5 \mathrm{M} 5 \mathrm{C} / \mathrm{SiO}_{2}$ was $\mathrm{C}_{17}$

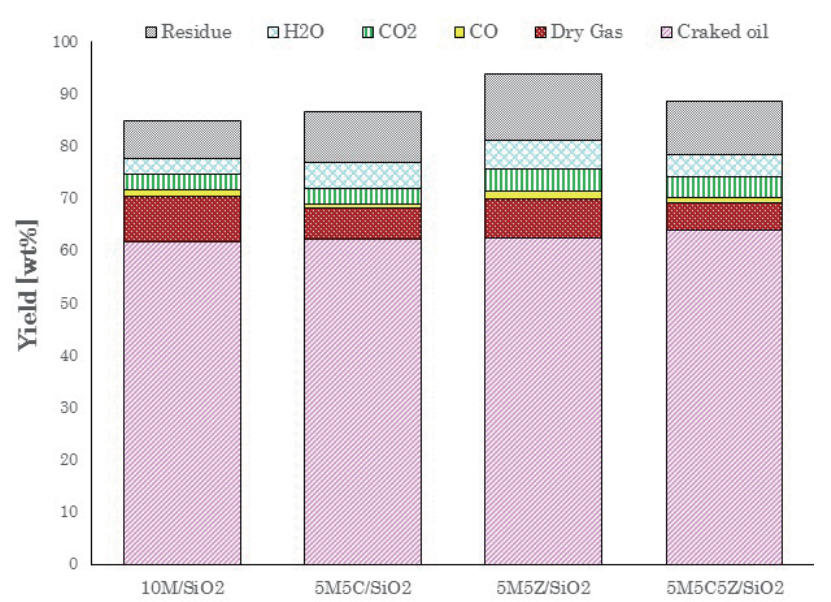

Fig. 4 Product yield from waste cooking oil over the oxide catalysts hydrocarbons, which would be originated from oleic acid group ( $\left.\mathrm{C}_{17} \mathrm{H}_{33} \mathrm{COO}-\right)$ and linoleic acid group $\left(\mathrm{C}_{17} \mathrm{H}_{31} \mathrm{COO}-\right)$ in the waste cooking oil. The $\mathrm{C}_{17}$ hydrocarbons could probably be produced from the triglycerides directly and after the decomposition to the corresponding free fatty acids, while the other hydrocarbons with shorter chain than $\mathrm{C}_{17}$ would be formed by the cracking of the alkyl groups in the reactants and the products. The lower yield of $\mathrm{C}_{17}$ with $5 \mathrm{M} 5 \mathrm{C} / \mathrm{SiO}_{2}$ catalyst suggests the higher cracking ability than the other catalysts. $\mathrm{C}_{21}$ compounds were found to be ketones as described above such as methyl ketone and ethyl ketone. Yield of these compounds increased by adding oxides, especially $\mathrm{ZrO}_{2}{ }^{13)}{ }^{14}$ )

Fig. 6 shows the acid value (AV) and iodine value (IV) of the cracked oils obtained over the four oxide catalysts. The acid values obtained with the binary $\mathrm{MgO}-\mathrm{CaO}$ and $\mathrm{MgO}-\mathrm{ZrO}_{2}$ catalysts and the ternary $\mathrm{MgO}-\mathrm{CaO}-\mathrm{ZrO}_{2}$ catalyst were about $12.0 \mathrm{mg}-\mathrm{KOH} / \mathrm{g}$-oil, and lower than that with $\mathrm{MgO}$ alone (14 mg-KOH/g-oil). This would mean the promotion of decarboxylation from the free fatty acid which

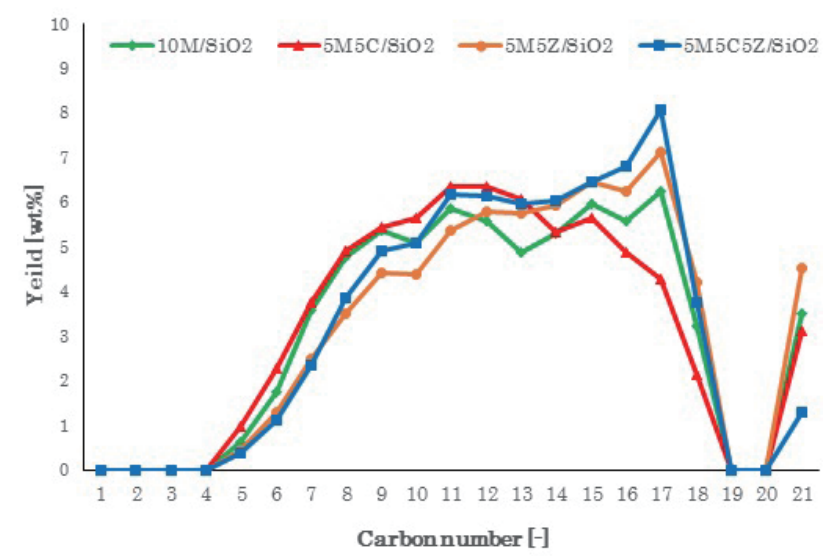

Fig. 5 Carbon number distribution of the product oil

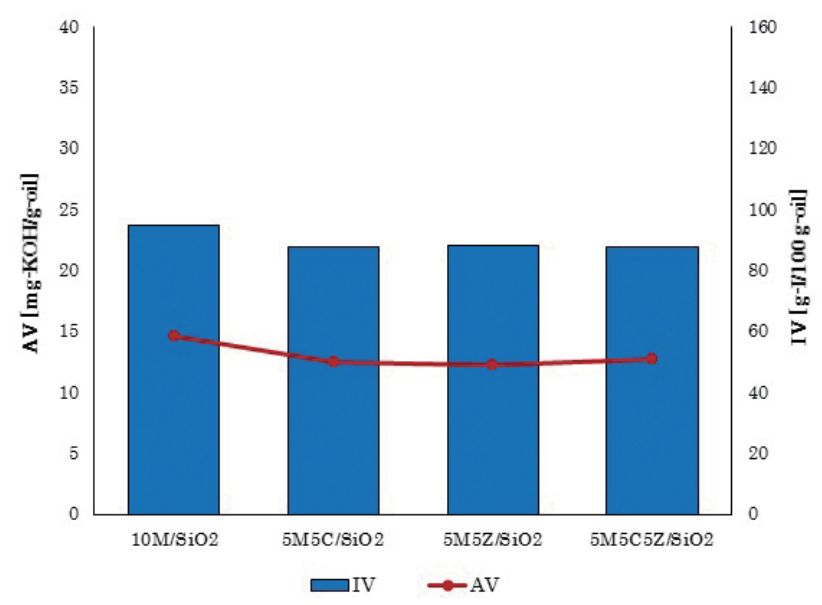

Fig. 6 The acid value and iodine value of the cracked oils 
are the intermediates from triglycerides to hydrocarbons. Although these values were slightly higher than the level of neat regulation $(0.5 \mathrm{mg}-\mathrm{KOH} / \mathrm{g}$-oil) for the biodiesel fuel, we have already developed an adsorption technique to clear the regulation for the oils with such acid values ${ }^{15)}$. Iodine values of all these oils were about $90 \mathrm{~g}-\mathrm{I} / 100 \mathrm{~g}$-oil, which were lower than the neat regulation (120 g-I/100 g-oil). The IV's obtained with the binary and the ternary oxide catalysts were slightly lower than that with $\mathrm{MgO}$ alone. The added $\mathrm{CaO}$ and $\mathrm{ZrO}_{2}$ might form new active sites and promote protonation and cracking of $\mathrm{C}=\mathrm{C}$ double bonds.

\section{Conclusion}

Effects of addition of $\mathrm{CaO}$ and $\mathrm{ZrO}_{2}$ to $\mathrm{MgO} / \mathrm{SiO}_{2}$ catalyst on the $\mathrm{HiBD}$ production from waste cooking oil have been investigated and the following conclusions were obtained. The binary $\mathrm{MgO}-\mathrm{CaO} / \mathrm{SiO}_{2}$ and $\mathrm{MgO}-\mathrm{ZrO}_{2} / \mathrm{SiO}_{2}$ catalysts and the ternary $\mathrm{MgO}-\mathrm{CaO}-\mathrm{ZrO}_{2} / \mathrm{SiO}_{2}$ catalyst were simply synthesized by incipient wetness impregnation method and could be directly used for the HiBD production. The catalyst exhibited good catalytic activities and promoted decarboxylation reaction, which gave higher $\mathrm{CO}_{2}$ yields than $\mathrm{MgO} / \mathrm{SiO}_{2}$, and showed lower acid values mainly due to their high surface area and pore volume.

\section{Acknowledgment}

This work was supported by JST-JICA SATREPS program and NEDO, Japan. Natewong P. is grateful to the support from the Japanese Government (Monbukagakusho) Scholarship

\section{References}

1) Saka, S., All About Biodiesel, IPC Inc, (2006)

2) Maeda, S., Sci. Tech. Trends, 11-27 (2007)

3) Tani, H.; Shimouchi, M.; Haga, H.; Fujimoto, K., J. Jpn. Inst. Energy, 90, 466-470 (2011)

4) Tani, H.; Hasegawa, M.; Asami, K.; Fujimoto, K., Catal. Today, 164, 410-414 (2011)

5) Asami, K.; Komatsu, Y.; Ono, K.; Murakami, Y.; Tani, H.; Fujimoto, K., J. Jpn. Petrol. Inst., 58, 293-301 (2015)

6) Murakami, Y.; Tani, H.; Asami, K.; Fujimoto, K., J. Jpn. Inst. Energy, 94, 1074-1078 (2015)

7) Jpn. Reg. Trade Mark, 5468299

8) Jiao, X.; Li, N.; Xiao, F.; Wei, W., Energy Fuels, 27 , 5407-5415 (2013)

9) Garcia, J.; Lopez, T.; Alvarez, M.; Aguilar, D. H.; Quintana, P., J. Non-Cryst. Solids, 354, 729-732 (2008)

10) Xu, H.; Chu, W.; Luo, J.; Zhang, T., Chem. Eng. J., 170, 419-423 (2011)

11) Chang, C. C.; Wang, S. W., Ind. Eng. Chem, 39, 1543-1548 (1947)

12) Watanabe, M.; Inomata, H.; Smith Jr, R. L.; Arai, K., Appl. Catal A, 219, 146-156 (2001)

13) Pestman, R.; Koster, R. M.; van Duijne, A.; Pieterse, J. A. Z.; Ponec, V., J. Catal, 168, (1997)

14) Watanabe, M.; Iida, T.; Inomata, H.: Energy. Convers. Manage, 47, 3344-3350 (2006)

15) Fujimoto, K.; Murakami, Y.; Tani, H.; Asami, K., Jpn. Pat. Appl, 19, 2014-2075 